\title{
Chapter 1: Women, punishment and social justice
}

\author{
Margaret Malloch and Gill McIvor
}

\section{Introduction and background}

In the last 20 years, there has been a growing international recognition that prison is an inappropriate response to women in conflict with the law and a subsequent concern among academics, policy-makers and practitioners to reduce the number of women imprisoned (Sudbury 2005; Sheehan, McIvor and Trotter 2011). Across jurisdictions, lawbreaking by women differs in a number of important ways from lawbreaking by men: it is less common, less frequent and less serious. Women are typically convicted of relatively minor crimes that pose little public risk and, because they are usually convicted of offences that are less serious than those committed by men, the sentences they receive are also different: for example, women are less likely than men to receive sentences of imprisonment. However, female imprisonment has increased dramatically in most western jurisdictions over the last 15-20 years as evidenced by increases in the numbers of women given sentences of imprisonment, in daily female prison populations and in the rate of imprisonment of women (McIvor 2010). Moreover, because the rise in women's imprisonment has outstripped parallel increases in the imprisonment of men, women now make up a greater proportion of prisoners. There is little evidence that more women are being imprisoned because of an increase in the seriousness of female offending: rather it appears that a complex range of factors are responsible including legislative changes and increasingly punitive responses to women in conflict with the law (McIvor and Burman 2011).

The prison has often been the focus for expressed concerns about human rights violations, and campaigns aimed at achieving social justice, for individuals and groups with an interest in the criminalisation of women (Amnesty International 1999; UN Special Rapporteur 1999; Canadian Human Rights Commission 2003; Shaw 2003; Northern Ireland Commission on Human Rights (Scraton and Moore 2005 and 2007); Human Rights Watch 2006; Sandler and Coles, 2008). There is little doubt that this attention is necessary and justified. Given the challenges which need to be overcome in addressing these entrenched and complex problems, it is little wonder that the prison retains the attention of those seeking change for women involved with the criminal justice system.

Despite a concerning growth in the number of older women being imprisoned, the majority of women in prison (around two-thirds) are mothers with children under 18 years of age. Imprisonment therefore impacts not just on women but also on the human rights of their children who will experience a variety of alternative (and often unstable) care arrangements while their mothers are serving a prison sentence and who may be unable to visit their mothers if they are imprisoned some distance from home (Caddle and Crisp 1994). Imprisoned women are subjected to intrusive searches and extensive 
surveillance that can exacerbate trauma associated with prior experiences of abuse and increase the risk of self harm (Scraton and Moore 2007). Levels of self harm and suicide are higher in female prisons than in male prisons, even though levels of suicide in the community are higher among men (Leibling 1992; Sandler and Coles 2008) and there are high levels of drug problems among women in prison (Malloch 2008). A high proportion of women who are imprisoned will lose their accommodation (and often their possessions) during their period of imprisonment, adding to the difficulties they experience resettling in the community on their release (Gelsthorpe and Sharpe 2007a; Morris, Wilkinson, Tisi, Woodrow and Rockley. 1995). Community penalties offer clear benefits insofar as they avoid the separation of mothers from their children alongside other practical and emotional consequences of imprisonment. However, attempts to address the needs of children at the point of sentencing raise additional and complex concerns. While, arguably, the potential impact of imprisonment on children should be a key consideration for sentencers this can potentially have deleterious consequences for women who do not have children, and for women presented in court as 'unfit mothers'.

Given that the growth in women in prison internationally does not appear to be underpinned by an increase in crimes committed by women (Hedderman 2004; McIvor and Burman 2011) policy initiatives have been developed to increase the use of community-based responses to criminalised women. These initiatives have tended to operate alongside reforms to the prison estate and their integral role as a form of punishment is evidenced by the terms used to define them: 'community punishment'; 'community sanctions'; 'community payback', 'alternatives to imprisonment'. These interventions are generally assumed to offer a more constructive and arguably more 'costeffective' (New Economic Foundation 2008) response to law-breaking by women, yet little is known about how different sanctions and measures are used with women across different jurisdictions and how they impact upon aspects of women's lives.

Ongoing attempts have been made to increase the opportunities and format of community sanctions - making existing resources more suitable for women and developing others which are 'gender-responsive' in design and delivery (Bloom, Owen and Covington 2003). Recent policy and practice initiatives have focused on the development of integrated services for criminalised women such as the 218 Centre in Scotland (Easton and Matthews 2011a; Loucks, Malloch, McIvor and Gelsthorpe 2006), Together Women in England and Wales (Hedderman, Palmer and Hollin 2008) and Inspire in Northern Ireland (Easton and Matthews 2011b) often alongside other disadvantaged women as in the Asha Centre (Roberts 2002), thereby enabling a wide range of needs to be met.

Three particular considerations arise in relation to community provisions. First, the ability to mobilise resources to meet women's needs depends on their availability in the first place and this is a particular challenge in the current economic climate with voluntary and public sector organizations facing funding cuts that compromise their ability to carry out vital functions that support criminalised women and their families. It is often an accumulation of events and experiences that result in women's criminalisation, therefore agency collaboration that spans a wide range of social policy areas is vital to address the wider social and economic context of women's circumstances 
and to tackle poverty, homelessness and other aspects of social disadvantage experienced by women. Thus while the developments taking place in relation to the introduction of community sanctions remain located within the criminal justice system, many of the factors associated with women's law-breaking are traceable to social, political and economic contexts. The absence of appropriate resources within communities, notably to address addiction, mental health problems, and gendered violence, leads to ongoing processes of criminalisation - and hence to an increase in the use of imprisonment.

Secondly, women often receive community penalties at an earlier point in their criminal careers than men and appear to face particular challenges in complying with community penalties as a result, among other things, of their responsibilities for children and other dependents. If these penalties are breached, then uptariffing is likely to arise as a result of the perception that they have exhausted the range of non-custodial penalties available to the courts. This suggests that enforcement practices need to be sufficiently flexible if high levels of breach (and resulting imprisonment) are to be avoided. Furthermore, while acknowledging that diverting women from prison is a central concern, diversion from community supervision for women convicted of minor offences is also important (particularly in relation to mental health issues and poverty) to prevent their unnecessary absorption into the criminal justice system.

Thirdly, attention needs to be paid to the human rights implications of community sanctions. For example, women are more likely than men to receive additional requirements relating to medical/psychiatric/psychological treatment or drug treatment, raising questions about the potential intrusion into family life, the experience of undergoing random (observed) drug tests and the lack of drug, and other services, that are specifically tailored to women (Malloch and McIvor 2011a and b).

In addition it is important to acknowledge that even the most innovative community sanctions can experience challenges as they operate within systems which remain geared to meet the disproportionate demands of the main users of criminal justice services who are men (McIvor 2004; Gelsthorpe and Sharpe 2007b; Malloch 2008). The introduction of the Gender Equality Duty in the UK and similar legislative obligations in place elsewhere, require that policies are subjected to a gender impact assessment to prevent discriminatory outcomes. Such requirements might be expected to impact on the treatment of women in the criminal justice system by requiring that programmes and interventions in prisons and in the community are planned specifically with women in mind, are based on evidence of women's needs and consider how relevant agencies will address the current lack of services to address these specific needs. Such measures are intended to ensure equality of treatment between men and women, which will not necessarily mean the same treatment. The importance of this distinction is evident (Bloom et al. 2003; Canadian Human Rights Commission 2003; Corston 2007) indicating the need to move from formal to substantive equality.

However, as previously noted, policy initiatives that have been developed to increase the use of community-based responses to criminalised women have tended to sit alongside reforms to the prison estate that are aimed at improving conditions in women's prisons 
(Carlen 2002; Hannah-Moffat 2001). As the Canadian experience in particular demonstrates, ostensibly well-intentioned correctional policies easily become subverted by criminal justice agendas and may ironically serve to enhance rather than challenge the legitimacy of imprisonment as a response to female crime. This book aims to go beyond a critique of gender-responsive approaches in order to examine responses to women in terms of human rights and social justice and this necessitates understanding structural imperatives. Women, Punishment and Social Justice: Human Rights and Penal Practices draws upon presentations and discussions that took place in a series of three workshops during 2010 as part of a programme of work funded by the Institute for Advanced Studies (now known as the Scottish Universities Insight Institute). The programme, and subsequently this book, originated from growing awareness that despite little evidence of an increase in crime committed by women, internationally the imprisonment of women had increased significantly in recent years, with its associated social, economic and personal costs. The chapters provide analyses from international experts on women and justice from countries across the UK and internationally focusing on arguments for, and attempts to address, the ever-increasing female prison population through the implementation of community alternatives. By viewing these initiatives through the discourse of human rights and social justice, their impact is examined critically, with consideration given to the wider social, political and economic context in which women are increasingly criminalised and punitive mechanisms imposed.

The principal aim of the programme was to consider how the number of women imprisoned can be reduced through more effective use of non-custodial alternatives that are consistent with the protection of women's human rights and promotion of social justice. The core objective was to draw upon international knowledge and expertise to critically assess cross cultural responses to lawbreaking by women and to provide a forum for academics, practitioners and policy makers to participate in the development of knowledge for policy, practice and research. Importantly, the programme also aimed to present a challenge to the increasing criminalization of social circumstances that profoundly affect women. Through an examination of the contexts within which punishment is enacted, it is evident that social, political and economic structures determine the experiences of the most marginalized groups in society. This is perhaps most clearly illustrated by considering the operation of punishment on indigenous women across the world and has consequences for penal practice in both prisons and the community.

As the contributions to this volume demonstrate, criminalised women are usually disadvantaged and victimised women who have been let down by the state, with increased penalisation of the welfare state having had a particular and pronounced impact on women. Prison may be perceived as capable of meeting the needs of women who have been 'failed' by the erosion of welfare services and often appears to be employed as a 'welfare panacea' or a form of respite for women with 'chaotic' lifestyles (Tombs and Jagger 2006). Thus while there have been some reported successes in reducing the use of custodial sentences for women through the development of gender-appropriate community based resources, a significant and sustained reduction in female imprisonment appears to be unachievable in the absence of wider political and public 
commitment and socio-economic change that enables women's needs to be met through mainstream, community-based service provision. The harms imposed by the imprisonment of women highlight the need for significant and radical penal reform and the need to recognize the relationship between criminal and social justice whereby existing social policies and their impact on health and other community services and resources result in the criminalization of poverty and distress. Thus while meaningful change will require sentencing reform, wider social changes are also imperative to address many of the issues which result in women's involvement with the criminal justice system.

As the contributions show, community penalties are often held up as the way forward for penal practices in relation to women, however, these interventions can be punitive in their own right, may extend women's involvement with the penal system, and highlight that 'gender-responsive programming' is deeply problematic. The very concept of 'community' is widely contested and under-theorised. Notably, even the most therapeutic programmes, when introduced within a criminal justice context, have been shown to individualise what are actually social problems. Therapeutic interventions come to be prioritized over structural issues and power relations. Highlighting the impact of processes of criminalization, and the ways in which gender is intersected by race/ethnicity and class, brings into sharper focus the potential depoliticisation of structural imperatives as they are enacted in penal practices. The gender-responsive model notably fails to address the intersection of injustices that characterize the lives of women in conflict with the law.

We have attempted to bring together a range of contributions which cover issues pertinent to both imprisonment and community punishments and which exemplify developments across a range of jurisdictions. Drawing upon experiences in other non-UK European jurisdictions proved something of a challenge, principally it would appear, because the topic of women and punishment (and especially their experiences of community sanctions) has received limited academic attention. We therefore hope that this book will help to promote research and debate on this topic.

\section{Organization and focus}

By taking social justice and human rights as a central focus, sharing experiences and research findings and identifying gaps in knowledge, this volume aims to make an innovative contribution to policy, practice, and to academic theory and analysis. The book is organized around key themes which are integral to the issues surrounding women, punishment and social justice. We aim to highlight gendered dimensions of treatment and the effects of new penal policies, the relationship between punishment and social inequality and between social justice and human rights.

Many activists believe that women are being marginalised in a criminal justice system that was designed for men and that, for this reason, there is a lack of women-focussed services both within and outside the prison. An examination of community provisions 
highlights the problematic relationship between the criminalisation and governmentality of women (within and outside the criminal justice system). This recognition requires the presentation of a challenge to the legitimacy of existing practice and policy that undermines equality and human rights legislation. Loraine Gelsthorpe (Chapter 2) addresses these issues by providing a theoretical examination of punishment and the impact of gendered ideologies in determining the operation and impact of punishment.

Women often end up in prison not because they have committed serious crimes but because alternative sanctions are considered inappropriate and prison may be viewed by sentencers as a form of respite for women with chaotic lifestyles. Yet prisons are places of isolation and violence and imprisonment can impact significantly upon women's relationships with their children and on their social circumstances on release, In these respects, it can be argued that society fails women in prison, where the conflict between professional ethics, human rights and correctional policy and practice is brought sharply into focus. Linda Moore and Ann Jemphrey (Chapter 3) challenge the centrality of the prison as a response to women's law-breaking in Northern Ireland, highlighting the gendered characteristics and experiences of incarcerated women within a social context characterized by social inequality and transition from social conflict. Their account highlights the remarkable consistency among women in prison internationally, characterized by the prevalence of mental health issues, substance misuse, experiences of abuse and substitute care and high levels of self-harm. This latter issue forms the basis of Chapter 4 in which Deborah Coles examines the human rights issues which arise from the criminalization of distress and the failure of reformist agendas to satisfactorily address the deeply troubling circumstances that remain a feature of the women's penal estate.

The criminalisation of women with mental health problems and the redefinition of their actions as reflecting behavioral or personality deficits is a theme that continues through many of the chapters. The expansion of health care interventions and subsequent healthfocused research in prisons fails, however, to recognize this issue. The inadequacy of existing methodologies to appropriately identify the mental health care needs of women in prison is addressed in Chapter 5 by Alice Mills, Kathleen Kendall, Judith Lathlean and Julie Steel who argue persuasively that women with mental health issues should not be in prison.

Women are not an homogenous group and their experiences of punishment, criminalisation and social justice vary alongside other structural dimensions such as age and ethnicity. In Chapter 6, Azrini Wahidin and Ron Aday discuss the needs of older women in prison in the UK and USA, highlighting the lack of attention to age-related health and other needs and the lack of adequate, age-related resettlement services for women leaving prison. The systemic discrimination that minority ethnic/indigenous women experience throughout the criminal justice system, as a reflection of the inherent discriminations which characterize wider society, are features of most of the chapters in this book. Margaret Malloch (Chapter 7) examines the innovative Okimaw Ohci Healing Lodge, a Correctional Service of Canada institution and considers the ways in which wider social inequalities permeate systems of punishment and 'healing' for Aboriginal women prisoners. 
The significance of interventions which aim to promote the systematic recognition and implementation of human rights in the institutional context is discussed by Alison Hosie (Chapter 8) as she outlines a programme of human rights reforms introduced in The State Hospital in Scotland, and considers the potential for a similar approach in women's prisons.

In order to achieve a paradigm shift, in which prison, instead of being a commonplace response to women in conflict with the law, becomes the exception, it will be necessary both to develop appropriate community provision for women and to enhance the legitimacy of new initiatives and differential provision, both in the eyes of sentencers and the wider public. The diverse causes of women's involvement with the criminal justice system arguably makes the issue more difficult to grapple with, though there is growing evidence that carefully considered community approaches can result in a range of improved criminal justice, health and other outcomes for women in ways that are less stigmatizing for women.

Garnering judicial and public support for decarceration and community alternatives may be assisted with reference to broader notions of 'harm' and allied to strong economic arguments against punishment. In Chapter 9, Jodie Lawston examines the expansion of punishment in the United States; arising from the inter-relationship between the prison and growing emphasis on punishment in the community which has contributed to the widening rather than contraction of carceral systems. Internationally there appears to be a reduced policy commitment to women in the criminal justice system and, as Rosemary Sheehan illustrates in Chapter 10 the election of a conservative (liberal) government in Victoria, Australia concerned with instituting tight fiscal controls has exacerbated the challenges for women in transition between prison and the community.

The ideological significance of community punishment has an impact that can be experienced within supportive interventions that aim to assist women under the rubric of a criminal justice system. Alana Barton and Vickie Cooper examine the 'semi-penal' paradox which is a feature of hostels for women and which, while having much to offer in terms of support, retain a distinctively gendered punitive capacity. Mary Beglan, in Chapter 12 offers an alternative perspective by outlining the operation of the 218 Service in Glasgow, Scotland which provides an important resource for women in the criminal justice system, but which operates in a number of ways outside it. Nevertheless, the challenges of implementing reforms through the justice system are re-visited by Una Convery (Chapter 13) in which she examines the Northern Ireland state's response to women within the criminal justice system and the development and operation of community punishments. In Chapter 14, Rosario Pozo Gordalize examines the significance of context further by highlighting the experiences of young Gitana women in Andalusia, Spain and the impact of punishment both within and outwith the criminal justice system as it is experienced by this group of socially marginalized young women in Spanish society. 
Kim Pate provides us with a call to action in Chapter 15 where she re-emphasises the necessity of collective action to address the social, political and economic inequalities which permeate societies and which, as the previous chapters have highlighted, are intertwined in process of criminalization and punishment. Margaret Malloch and Gill McIvor underline this in Chapter 16 where they provide some concluding reflections, underlining the recognition, which features prominently throughout the book, that penal reforms cannot transcend structural imperatives and that meaningful change will require a more radical approach.

\section{References}

Amnesty International (1999) Not Part of my Sentence: Violations of the Human Rights of Women in Custody, USA: Amnesty International.

Barry, M. and McIvor, G. (2008) Chaotic Lives: A Profile of Women in the Criminal Justice System in Lothian and Borders, Edinburgh: Lothian and Borders Community Justice Authority.

Bloom, B., Owen, B., and Covington, S. (2003) Gender-Responsive Strategies: Research, Practice, and Guiding Principles for Women Offenders Project Guiding Principles and Strategies Draft Document, Washington, DC: National Institute of Corrections.

Caddle, D. and Crisp, D. (1997) Imprisoned Women and Mothers, Home Office Research Study 162, London: Home Office.

Canadian Human Rights Commission (2003) Protecting Their Rights: A Systemic Review of Human Rights in Correctional Services for Federally Sentenced Women, Ottawa: Canadian Human Rights Commission.

Carlen, P. (2002) 'Carceral clawback: The case of women's imprisonment in Canada',. Punishment and Society, 4 (1): 115-21.

Corston,J. (2007) A Review of Women with Particular Vulnerabilities in the Criminal Justice System, London: Home Office.

Easton, H. and Matthews, R. (2010) Evaluation of the 218 Centre: Examining Implementation and Outcomes, Glasgow: Glasgow City Council.

Easton, H. and Matthews, R. (2011) Evaluation of the Inspire Women's Project, Belfast: Northern Ireland Department of Justice. 
Gelsthorpe, L. and Sharpe, G. (2007a) 'Women and resettlement', in A. Hucklesby and L. Hagley-Dickinson (eds) Prisoner Resettlement: Policy and Practice, Cullompton: Willan Publishing.

Gelsthorpe, L. and Sharpe, G. (2007b) Provision for Women Offenders in the Community, London: Fawcett Society.

Hannah-Moffat, K. (2001) Punishment in Disguise: Penal Governance and Canadian Women's Imprisonment, Toronto: University of Toronto Press.

Hedderman, C. (2004) 'Why are more women being sentenced to custody?', in G. McIvor (ed) Women Who Offend, London: Jessica Kingsley.

Hedderman, C., Palmer, E. and Hollin, C. (2008) Implementing Services for Women Offenders and Those 'At Risk' of Offending: Action Research with Together Women, London: Ministry of Justice.

Human Rights watch (2006) Custody and Control: Conditions of Confinement in New York's Juvenile Prisons for Girls, New York: American Civil Liberties Union/Human Rights Watch.

Leibling A (1992) Suicides in Prison, London: Routledge.

Loucks, N., Malloch, M., McIvor, G. and Gelsthorpe, L. (2006) Evaluation of the 218 Centre, Edinburgh: Scottish Executive.

Malloch, M. (2008) 'A spoonful of sugar? Treating women in prison', in T. Anderson (ed) Neither Villain Nor Victim, London: Rutgers University Press.

Malloch, M. and McIvor, G. (2011a) 'Women and community sentences', Criminology and Criminal Justice, 11 (4): 325-44.

Malloch, M. and McIvor, G, (2011b) 'Women, drugs and community intervention', in R. Sheehan, G. McIvor and C. Trotter (eds) Working with Women Offenders in the Community, Cullompton: Willan Publishing.

McIvor, G. (2004) 'Service with a smile? Women and community 'punishment', in G. McIvor (ed) Women who Offend, London: Jessica Kingsley Publishers.

McIvor, G. (2010) 'Women and crime: The rise in female imprisonment in western jurisdictions', in M. Herzog-Evans (ed) Transnational Criminology Manual, Nijmegen, Netherlands: Wolf.

McIvor, G. and Burman, M. (2011) Understanding the Drivers of Female Imprisonment in Scotland, Stirling and Glasgow: Scottish Centre for Crime and Justice Research. 
Morris, A., Wilkinson, C., Tisi, A., Woodrow, J. and Rockley, A. (1995) Managing the Needs of Female Prisoners, London: Home Office

New Economic Foundation (2008) Unlocking Value: How We All Benefit from Investing in Alternatives to Prison for Women Offenders, London: NEF.

Roberts, J. (2002) 'Women-centred: The West Mercia community-based programme for women offenders', in P. Carlen (ed) Women and Punishment: The Struggle for Justice Cullompton: Willan Publishing.

Sandler, M. and Coles, D. (2008) Dying on the Inside: Examining Women's Deaths in Prison, London: INQUEST.

Scraton, P. and Moore, L. (2005) The Hurt Inside, Belfast: Northern Ireland Human Rights Commission.

Scraton, P. and Moore, L. (2007) The Prison Within, Belfast: Northern Ireland Human Rights Commission.

Shaw, S. (2003) The Death in Custody of a Woman and the Series of Deaths in HMP/YOI Styal, August 2002-2003, London: Report by the Prisons and Probation Ombudsman for England and Wales.

Sheehan, R., McIvor, G. and Trotter, C. (eds) Working with Women Offenders in the Community, Cullompton: Willan Publishing.

Sudbury, J. (ed) (2005) Global Lockdown: Race, Gender and the Prison-industrial Complex, New York: Routledge.

Tombs, J. and Jagger, E. (2006) 'Denying responsibility: Sentencers' accounts of their decisions to imprison', British Journal of Criminology, 46: 803-21.

UN Special Rapporteur (1999) Integration of the Human Rights of Women and the Gender Perspective, United Nations Commission on Human Rights. 